\title{
Prevalensi Kelainan Refraksi pada Siswa SD Negeri 09 Pagi Tanah Tinggi Jakarta Pusat
}

\section{The Prevalence of Refractive Disorder in Students of State Elementary School 09 Tanah Tinggi of Central Jakarta}

\author{
Saskia Nassa Mokoginta ${ }^{1,4}$, Himmi Marsiati ${ }^{2,4}$, Atiek Indriawati ${ }^{1,4}$, Tri Panjiasih Susmiarsih ${ }^{3}$ \\ E-mail: Saskia.nassa@yarsi.ac.id \\ ${ }^{1}$ Departement of Opthalmology, Fakulty of Medicine, Universitas YARSI \\ ${ }^{2}$ Departement of Biochemistry, Fakulty of Medicine, Universitas YARSI \\ ${ }^{3}$ Departement of Biology, Fakulty of Medicine, Universitas YARSI \\ ${ }^{4}$ YARSI Save Vision Center, Universitas YARSI
}

KEYWORD Refractive examination, refractive disorder, elemantary school student

ABSTRACT Based on survey results of the Ministry of Health of the Republic of Indonesia reported in 1996 the highest prevalence of eye disease is refractive disorder, which is $24.72 \%$. An estimated 12 million children from 19 million children suffering from blindness have refractive disorders. The purpose of this study is to obtained the prevalence of refractive disorder in children of State Elementary School Tanah tinggi 09 Central Jakarta. Refractive examination was conducted on 103 children at SD Negeri 09 Tanah Tinggi with 7-12 years old using Snellen Chart, LEA Chart, Autorefractors meter and Streak retinoscopy and also given glasses correction with glasses supplied. The prevalence of refractive abnormalities has been obtained from the refractive examination.There were 103 children examined, 53 of them suffering from refractive disorder with 51,46\%. From the 53 people, 47 people with 88,68\% diagnose with myopia simplex and 6 people with 11,32\% was diagnose with Astigmatisme Myopia Compositus. Prevalence of refraction disorder based on Degrees of myopia, we found 46 people with low myopia (<3.00 Diopter), moderate (3 - 5 Diopter) and 2 people with high myopia (>6 Diopter) Diopters). The prevalence of Refractive Abnormalities in children at SD Negeri 09 Tanah Tinggi is quite high at $51.46 \%$.

\section{PENDAHULUAN}

Penglihatan adalah salah satu dari panca indera kita yang amat penting. Mata merupakan organ yang dapat menerima informasi secara visual untuk melakukan aktivitas sehari-hari. Gangguan penglihatan

yang ringan sampai berat dapat menyebabkan kebutaan yang menurunkan kualitas hidup seseorang dan bangsa.
Tumbuh kembang mata manusia berlangsung sangat cepat sejak bayi dan awal masa kanak-kanak. Selanjutnya akan berlangsung sampai mencapai seperti orang dewasa pada usia 12 tahun. (American Academic of Ophthalmology, 2009). Mata pada bayi baru lahir adalah hiperopik dan bertambah hiperopik sampai usia 7 tahun menuju miopisasi serta memiliki ukuran bola mata dewasa pada usia 16 tahun.

Selama periode ini dapat terjadi kelainan refraksi yang berbeda pada satu 
anak dengan anak lainnya. Bila terjadi miopia lebih muda

dari 10 tahun, akan berpotensi terjadinya miopia yang progresif sampai mencapai 6 dioptri (American Academic of Ophthalmology, 2009), oleh karena itu pemeriksaan mata harus dilakukan sejak bayi agar kelainan yang terjadi dapat diketahui lebih dini dan mendapatkan terapi secepatnya sehingga prognosis untuk tajam penglihatan akan lebih baik.

Penyebab gangguan penglihatan terbanyak di seluruh dunia adalah kelainan refraksi yang tidak terkoreksi, katarak dan glaukoma. Sebesar $18 \%$ tidak dapat ditentukan dan $1 \%$ adalah gangguan penglihatan sejak masa kanak-kanak. (WHO 2013). Kelainan refraksi yang tidak terkoreksi merupakan penyebab utama low vision di dunia dan dapat menyebabkan kebutaan.

Kelainan refraksi merupakan kelainan pada mata yang paling umum. Hal ini terjadi apabila mata tidak mampu memfokuskan bayangan dengan jelas, sehingga penglihatan menjadi kabur, dimana kadang-kadang keadaan ini sangat berat sehingga menyebabkan kerusakan padapenglihatan (WHO, 2013). Tiga kelainan refraksi yang paling sering dijumpai yaitu miopia, hipermetropia, dan astigmatisme. Kelainan refraksi dapat diakibatkan oleh kelainan kurvatur atau kelengkungan kornea atau lensa, indeks bias atau refraktif berkurang pada lensa matur, ataupun karena kelainan aksial atau sumbu mata (Ilyas, 2006). Prevalensi kebutaan di ASEAN adalah sekitar 0,8\%. Thailand sebesar $0,3 \%$ dan Indonesia sebesar $1,5 \%$ di Indonesia. Indonesia merupakan negara dengan angka kebutaan yang tertinggi dibandingkan dengan negara-negara ASEAN lainnya. Riskesdas (2013) mendapatkan data mengenai kesehatan indera penglihatan dari responden berjumlah 924.780 orang berusia 6 tahun ke atas. Hasil Riskesdas menunjukkan prevalensi kebutaan cenderung lebih rendah dibandingkan prevalensi kebutaan tahun 2007. Prevalensi kebutaan tertinggi ditemukan di Gorontalo $(1,1 \%)$ selanjutnya diperoleh prevalensi kebutaan di Nusa Tenggara Timur sebesar $1,0 \%$, Sulawesi Selatan dan Bangka Belitung masing-masing sebesar $0,8 \%$.

Angka yang cukup tinggi pada anak usia 6 tahun ke atas ini perlu ditekan kembali. Untuk itu perlu dilakukan upaya pemeriksaan kelainan refraksi mata pada anak anak sekolah dasar sehingga dapat segera dilakukan koreksi dan diterapi sedini mungkin selain itu perlu diketahui tingkat kelainan refraksi mata pada anak anak sekolah dasar.

\section{METODOLOGI}

Penelitian ini adalah survei deskriptif analitik dengan desain cross sectional bersifat observasi. Populasi dari penelitian ini adalah siswa SD Negeri 09 Tanah Tinggi Jakarta dan sampel yang dipilih secara random sederhana sebanyak 103 orang siswa yang telah memenuhi kriteria inklusi yaitu siswa kelas I sampai kelas $\mathrm{V}$, jenis kelamin perempuan dan laki-laki dengan kondisi kedua mata dalam keadaan sehat dan tidak cacat. Seluruhnya bersedia sebagai obyek penelitian sampai selesai. Penelitian ini dilakukan dengan cara pemeriksaan mata lengkap untuk menentukan jenis kelainan refraksinya menggunakan Snellen Chart, LEA Chart, Autorefraktometer dan Streak skiaskopi. Klasifikasi miopia berdasar derajatnya dengan skala D (dioptri) :

- Miopia ringan ( $<3.00 \mathrm{D})$

- Miopia sedang ( 3.00 D-6.00

D)

\section{ISI}

- Miopia berat ( > 6.00 D)

Kelainan refraksi terutama miopia banyak terjadi pada anak usia sekolah termasuk remaja. Berdasarkan penelitian yang telah dilakukan di Cina, India, dan Malaysia, diperoleh data bahwa lebih dari $41 \%$ 
remaja menderita miopia dengan tingkat koreksi -1,00 D dan lebih dari 80\% dengan ukuran -0,50\% D (Wu et al., 2001). Walaupun kelainan refraksi sudah cukup banyak terjadi dan umum di masyarakat, namun pengetahuan mereka mengenai gangguan refraksi ini masih belum cukup. Padahal pengetahuan ini sangat penting terutama mengenai koreksi kelainan refraksi. Jika kelainan refraksi tidak dikoreksi dapat menimbulkan komplikasi seperti esotropia (juling ke dalam) bahkan kebutaan. Selain itu, penderita dengan kelainan refraksi akan memberikan keluhan seperti sakit kepala terutama di daerah tengkuk atau dahi, mata

berair, cepat mengantuk, mata terasa pedas, pegal pada bola mata, dan penglihatan kabur. Miopia terjadi karena ketidaksesuaian antara kekuatan refraksi media refraksi dengan panjang sumbu bola mata dimana berkas sinar paralel yang masuk berkonvergensi pada suatu titik fokus di anterior retina. Kelainan ini bisa dikoreksi dengan lensa divergen/lensa minus() Dari hasil pemeriksaan dari 103 siswa diketahui sebanyak $53 \quad(51.46 \%)$ siswa mengalami kelainan refraksi dan 50 $(48.54 \%)$ siswa termasuk normal atau emetrop (Gambar 1). Distribusi prevalensi kelainan refraksi pada siswa di sekolah SD Negeri 09 ini adalah tinggi (51.46\%). Dari 53 siswa siswi yang mengalami kelainan refraksi, berdasarkan derajat myopia dapat diperoleh prevalensi myopia ringan adalah sebesar $87 \%$ ( 46 orang ), 9\% myopia sedang ( 5 orang ) dan $4 \%$ myopia berat (2 orang ) (Gambar

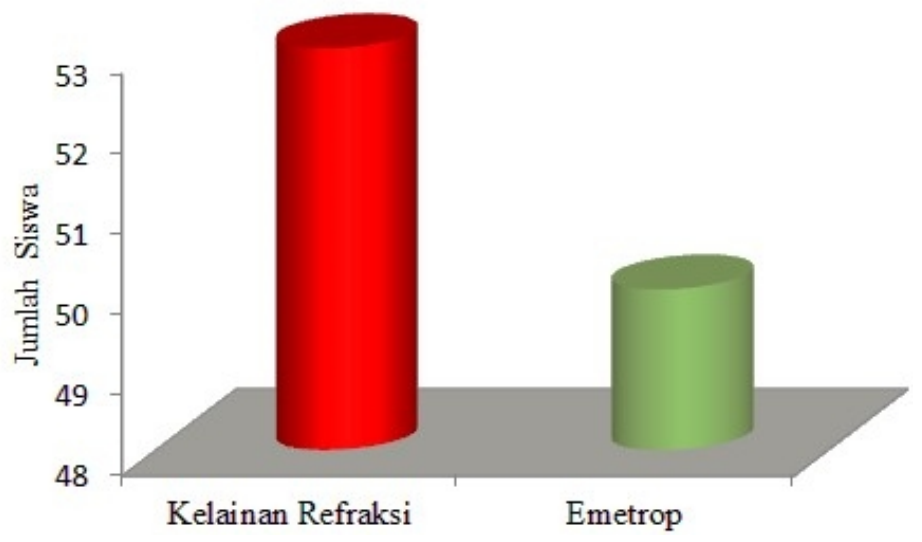

Gambar 1. Jumlah penderita kelainan refraksi dan normal atau emetrop pada siswa siswi SD Negeri 09 Tanah Tinggi Jakarta Pusat.

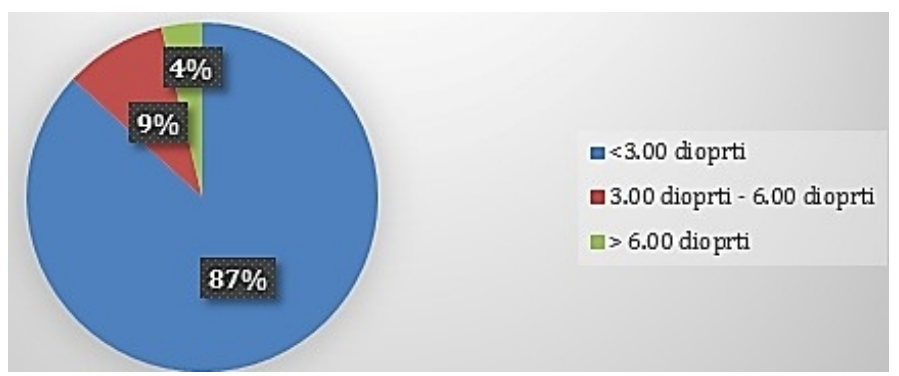

Gambar 2. Diagram prevalensi berdasarkan derajat myopia pada siswa siswi SD Tanah Tinggi 09 Jakarta Pusat 
Hasil penelitian yang diperoleh ini sesuai dengan survey prevalensi kelainan refraksi yang dilakukan oleh American Optometric Association (2006) bahwa anak-anak usia sekolah mengalami kelainan refraksi yang terbanyak adalah myopia. Hasil penelitian ini menunjukkan derajat dari myopia yang dialami siswa siswi namun belum dilakukan karakterisasi dari myopia yang dialami siswa. Untuk itu diperlukan penelitian lanjutan guna mendapatkan data karakteristiknya.

Myopia disebut juga sebagai rabun jauh. Miopia merupakan suatu keadaan mata yang mempunyai kekuatan pembiasan sinar yang berlebihan atau kerusakan refraksi mata sehingga sinar sejajar yang datang dibiaskan di depan retina (bintik kuning) dimana sistem akomodasi berkurang. Hal ini disebabkan oleh panjang aksial bola mata lebih panjang dibandingkan dengan mata normal pada umumnya. Pasien miopia mempunyai pungtum remotum (titik terjauh yang masih dilihat jelas) yang dekat sehingga mata selalu dalam atau berkedudukan konvergensi yang akan menimbulkan keluhan astenopia konvergensi. Kelainan ini diperbaiki dengan lensa negatif sehingga bayangan benda tergeser ke belakang dan tepat jatuh di retina.Pengaburan pada retina ini mencetuskan proses biokomia di retina untuk merangsang perubahan biokimia dan memicu beberapa modulator seperti asetilkolin, dopamin, vasoactive intestinal polypeptide dan enkephalins, ZENKglukagon serta beberapa faktor pertumbuhan lainya, yang mengakibatkan perubahan dalam sintesis mRNA dan konsentrasi susunan metalloproteinase sehingga perubahan - perubahan tersebut mengubah lingkungan visual dengan memicu pertumbuhan retina, koroid dan sklera yang menyebabkan pemanjangan aksial pada bola mata (Diether et al. 2001; Canadian Association of Optometrist (CAO), 2010)
Hasil survei yang dilakukan di Amerika Serikat menunjukkan bahwa prevalensi myopia meningkat pada usia sekolah sampai dewasa muda. Prevalensi myopia pada anak usia sekolah mencapai 20-25\% dan sampai dewasa muda sebesar 25-35\% (American Optometric Association, 2006 ). Pada penelitian ini, siswa siswi yang mengalami myopia berkisar antara usia 7 - 12 tahun dan yang terbanyak adalah usia 11 tahun sebanyak 16 orang (Gambar 3). Anak-anak yang mengalami kelainan refraksi sering tidak mengeluhkan gangguan penglihatan. Mereka hanya menunjukkan gejala-gejala yang menandakan adanya gangguan penglihatan melalui perilaku mereka sehari-hari (Hutahuruk, 2009) 


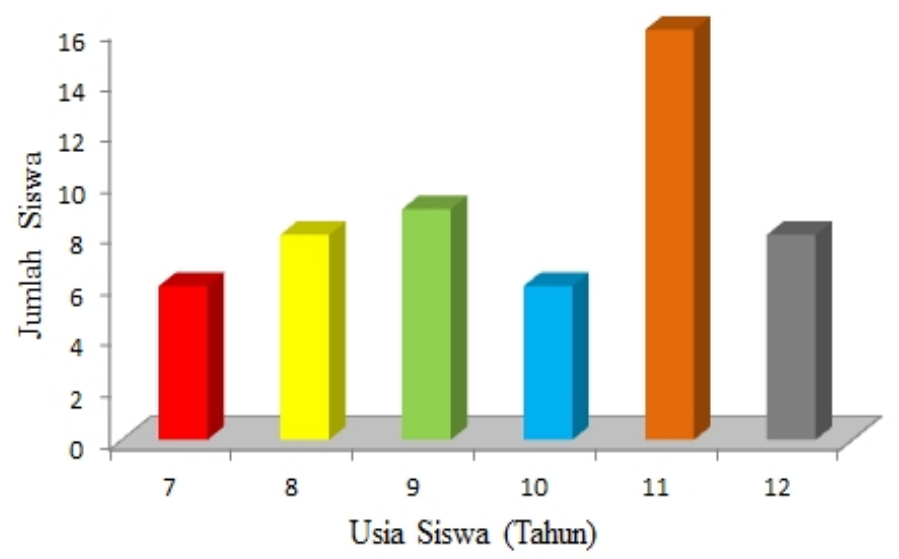

Gambar 3. Distribusi frekuensi kelainan refraksi berdasarkan usia pada siswa siswi SD Negeri 09 Tanah Tinggi Jakarta Pusat

Hasil penelitian ini dapat menambah data distribusi frekuensi usia (7-12 tahun) kelainan refraksi mata karena data hasil penelitian dengan responden pasien dari Klinik Mata Rumah Sakit Umum Sanglah di Denpasar Bali mendapatkan myopia merupakan kelainan refraksi yang banyak terjadi pada usia 11 - 20 tahun yaitu 25,1\% (Handayani et al., 2011). Responden yang digunakan dalam penelitian pada siswa SD ini didasarkan bahwa perkembangan retina dan saraf penglihatan terjadi sejak lahir sampai usia 12 tahun.

Ada beberapa faktor yang menyebabkan myopia, diantaranya faktor genetik dan lingkungan. Prevalensi miopia pada anak dimana kedua orang tuanya miopia adalah $32,9 \%$, jika salah satu orang tuanya miopia berkurang menjadi $18,2 \%$ dan jika tidak ada orang tuanya myopia adalah 6,3\% (Dirani et al., 2008). Pada penelitian anak kembar di Australia diperoleh data bahwa faktor genetik $50 \% \quad$ mempengaruhi pemanjangan aksis bola mata (Morgan, 2003). Penelitian di Tanzania menunjukkan bahwa orangtua yang memiliki status pendidikan tinggi cenderung mempunyai anak yang menderita myopia akibat adanya kondisi lingkungan yang diwariskan misalnya kesukaan membaca (Mutti et al., 2002).

\section{PENUTUP}

Dari 103 siswa siswi SD Negeri 09 Tanah Tinggi Jakarta Pusat yang mengalami kelainan refraksi adalah 53 orang $(51,46 \%)$ dan yang emetrop atau normal sebanyak 50 orang $(48,54 \%)$. Kelainan refraksi yang paling banyak dialami adalah myopia. Prevalensi myopia ringan sebesar $87 \%$, sedang $9 \%$ dan berat $4 \%$. Berdasarkan usia, myopia ini lebih banyak dialami siswa yang berusia 11 tahun namun masih diperlukan penelitian lebih lanjut untuk mengetahui karakteristik kelainan refraksi pada anakanak usia sekolah.

\section{DAFTAR PUSTAKA}

American Optometric Association. 2006 Optometric Clinical Practice Guideline Care of The Patient with Myopia, reviewed 2006. Page 3-8. 
Canadian Association of Optometrist (CAO). Work Life Balance. Royal Center Vancouver: Canadian Association of Optometrist. 2010.14

Curtin B.J. The Myopia.Philadelpia

Diether S. Gekeler F. dan Schaeffel F. Change in Contrast Sensitivity Induced by Defocus and Their Possible Relations to Emmetropization in The Chikcen. Invest Ophthalmol Vis Sci.2001.42 :3079-9.

Dirani M, Chambulain M, Shekar SN, Katz J, Rahi JS, Newman DK, Thylefors B. Heritability of Refrative Error and Ocular Biometic: The Gene in Myopia (GEM) Twin Study.Opthalmology and Visual Science. 2008.49(10): 4336-433.

Handayani AT,Supradnya IGN, Pemayun-DCI. 2012. Characteristic of pasients with refractive disorder at Eye Clinic of Sanglah General Hospital Denpasar,Bali-Indonesia. Periode of $1^{\text {st }}$ January $-31^{\text {st }}$ December 2011. Bali Medical Journal (BMJ); 1 (3) page 101-107.

Hutahuruk M. 2009. Hubungan Antara Pengetahuan Dengan Sikap Orangtua Tentang Kelainan Refraksi Pada Anak. [Skripsi]. Semarang: FK Universitas Diponegoro.

llyas S. Penuntun Ilmu Penyakit Mata. Edisi ke-3. Jakarta: FK UI. 2006.64-88.

Morgan IG. The Biological Basis of Myopic Refractive error. Clin Exp optom.2003.86(5): 276-88.

Mutti O, Mitchell L,Moescheberger ML, Invers RQ, Orsoni JG. Parental myopia, Near Work, School Achievement and Children's Refractive Error. Investigative
Opthalmology and Visual Science. 2002.43:12.

Riset Kesehatan Dasar (Riskesda). 2013. Badan Penelitian Dan Pengembangan Kesehatan Kementerian Kesehatan RI

World Health Organization (WHO). 2013. Universal eye health: a global action plan 2014-2019.

Wu HM, Seet B, Yap EP, Saw SM, Lim $\mathrm{TH}$, Chia KS. Does education explain ethnic differences in myopia prevalence? A populationbased study of young adult males in Singapore. Optom Vis Sci. 2001 Apr;78(4):234-9. 
